\title{
Eastern Sumbanese Bird Classification and Nomenclature: Additions and Revisions
}

\author{
Gregory Forth ${ }^{1 *}$ \\ ${ }^{1}$ Department of Anthropology, University of Alberta, Canada. \\ *'gforth@ualberta.ca
}

\begin{abstract}
Expanding on previously published research into folk classification of birds in the eastern part of the Indonesian island of Sumba, this article reports new information on bird categories and classification recorded by the author in 2015. New folk taxa are described and identified and scientific identifications for previously reported taxa are added or revised. Information on local bird classification from the Kambera region is compared with data recorded in the 1970 s in the district of Rindi, and these are shown to reveal only minor differences. Employing Berlin's well-known analytical scheme, the main features of the taxonomy are summarized and totals are enumerated for monotypic and polytypic folk-generics and both named and unnamed (covert) folk-intermediates. Additional information is provided concerning symbolic uses of bird categories, including bird names used as place names and local beliefs about nightjars (Camprimulgus spp.) which correspond to ideas encountered on the ethnozoologically better-known neighboring island of Flores.
\end{abstract}

Received December 24, 2015

OPEN ठACCESS

Accepted March 18, 2016

DOI 10.14237/ebl.7.1.2016.572

Keywords Bird classification, Folk taxonomic analysis, Bird names, Sumba Island, Eastern Indonesia

Copyright (c) 2016 Forth; licensee Society of Ethnobiology. This is an open-access article distributed under the terms of the Creative Commons AttributionNonCommercial 4.0 International Public License (https://creativecommons.org/licenses/by-nc/4.0), which permits non-commercial use, distribution, and reproduction in any medium, provided the original author and source are credited.

In an article published in Journal of Ethnobiology (Forth 2000), I examined the classification of birds found in the eastern region of the Indonesian island of Sumba. For this purpose, I drew on named categories of birds recorded in dictionaries by Kapita (1982) and Onvlee (1984), both of whom drew primarily on linguistic and taxonomic data recorded in the 1920s by the Dutch zoologist K.W. Dammerman. Also included was information I myself recorded on Sumbanese bird knowledge during ethnographic fieldwork conducted in the district of Rindi in 1975-76. Although the material reviewed in that article was sufficient to determine the main features of eastern Sumbanese bird classification and nomenclature, as I indicated, several lacunae remained both in regards to names for several kinds of birds and international scientific taxa associated with Sumbanese names.

In June-July and again in August of 2015, I was able to pay further visits to Sumba, where I stayed for a total of nearly three weeks, lodging in the traditional settlement of Parai Liu, located in the Kambera district, some two kilometers east of the main port town of Waingapu on Sumba's northeast coast. From there I made brief trips to Rindi, located about $70 \mathrm{~km}$ southeast of Waingapu, and to the interior district of Lewa. On the basis of information collected during this revisit I am now able to fill gaps in the data published in 2000 and to provide corrections to provisional identifications. I also review several general findings regarding the structure and content of eastern Sumbanese folk taxonomy of birds.

The eastern half of Sumba island reveals a high degree of linguistic uniformity and although several dialects can be identified these are mutually intelligible. The Kambera dialect is the main dialect of eastern Sumbanese. It is therefore used as a lingua franca in other eastern regions and was the dialect employed by both Onvlee and Kambera in their respective dictionaries and in translations of the New and Old Testaments, in the production of which both men assisted. Although revealing influence from the more distinct dialect of Mangili, spoken to the south of Rindi, the Rindi dialect itself differs only slightly from Kambera. Rather more distinct from both is the dialect of Lewa, a region located some $60 \mathrm{~km}$ southwest of Waingapu. Nevertheless, in this case the 
differences are not great and in general the naming and classification of birds found in Kambera, Rindi, and Lewa is broadly similar. What differences exist are noted below.

In each location, information on birds was derived from ethnographic conversations with individuals and small groups. More directive questions concerning particular birds and bird names were put to 14 men and one woman mostly selected opportunistically—seven from Kambera; five from Rindi, and three from Lewa. Of the total, three informants (including the woman) were 65 or older; six were between 55 and 64; three were between 45 and 50; and the remaining three were in their thirties. In Kambera most information was provided by a man aged 67 years, locally regarded as especially knowledgeable about birds. All informants were fluent in local dialects of eastern Sumbanese as well as in the Indonesian national language (Bahasa Indonesia). All had received some schooling, mostly at the primary level, while most younger informants had attended secondary school. As might be expected, older informants were more knowledgeable about indigenous categories. Questioning was conducted in a combination of Bahasa Indonesia and eastern Sumbanese, in which I gained fluency during my doctoral fieldwork conducted from January 1975 to December 1976.

\section{Newly Recorded and Revised Folk-Generics}

New named categories and identifications recorded in 2015 are listed below in alphabetical order:

Abu ramuku, egret Egretta spp., Bubulcus ibis. Kambera informants described the bird as resembling herons (nggokaria) and occurring mostly in wet rice fields, but being smaller than herons and having white plumage. The name translates as "pool, pond dog" (abu, dog; ramuk $u$ also refers to a buffalo wallow) and is reminiscent of abu omangu ('forest dog'), a euphemism used for monkeys when speaking of the primates in the presence of pregnant women. There is no indication that abu ramuku is a subordinate taxon subsumed in nggokaria, otherwise denoting larger kinds of herons. Nggokaria are recognized as varying in size and color of plumage but the birds thus designated were nevertheless described as composing a single "kind" (Indonesian jenis). Kapita (1982) and Onvlee (1984) both list abu ramuku as a term for 'sandpiper' in Mangili (Kapita's native district in southeastern Sumba). Kambera informants, however, contradicted this identification. Nor had anyone heard pipi, the term both Onvlee and Kapita give for "sandpiper," used as the name of a bird, and I was able to confirm that the sole term for sandpipers in Kambera was kabubu (Forth 2000). While on the topic of water birds, it may also be noted that Australian pelicans Pelecanus conspicillatus, which are irregular visitors on Sumba (Coates and Bishop 1997:233), are known only as pelikan, the Indonesian variant of the English name.

Kapiru, bee-eater Merops spp: Blue-tailed bee-eater $M$. superciliosis or Rainbow bee-eater M. omatus, two similar species both common on Sumba. The name was given by informants in reference to a bee-eater observed near Parai Liu in August 2015. Kambera people described kapiru as colorful birds with a long thin bill and a "spine" in the centre of the tail; as occurring most often near bodies of water (including the nearby Kambaniru river); and as digging holes in earthen banks in order to nest-all features that accurately characterize bee-eaters. As noted in Forth (2000), Kapita identifies kapiru as a pitta—small, round, short-tailed and relatively long-legged colorful birds of the family Pittidae-presumably referring to the Elegant pitta Pitta elegans, the only species recorded for Sumba (Coates and Bishop 1997). That Onvlee also understood kapiru as referring to a pitta is clear from the fact that his Dutch gloss, "grondlijster" (literally "ground thrush"), is an (older) Dutch term for pittas (Olivier 1931). There is, however, no indication that Sumbanese regularly apply the term to pittas as well as to bee-eaters. Not only are the two birds morphologically and behaviorally very different, but a photograph of a pitta shown to Parai Liu informants was not recognized as resembling any local bird, nor did my description of the distinct form of pittas elicit any response. Pittas, moreover, are shy and secretive birds that inhabit forest floors (Coates and Bishop 1997:390), and they are therefore likely to go unnoticed by most Sumbanese.

Mabibi (Kambera; in Lewa mabibu) a small rail (Rallidae), probably the White-browed crake Poliolimnas (Amauromis) cinerea. Although this name is listed in Forth (2000), it is not identified. Kambera informants described mabibi as a water bird often found in paddy fields. According to a more detailed description, the plumage is mostly gray or light brown, possibly with some darker brown; the legs are long; and the bill is quite long. Sometimes but not invariably the leg color is yellow. The birds build nests in reeds 
or grass in or near rice fields where they lay four to six eggs. Sumbanese hunt the birds by catching them at night with kerosene lamps, the light of which transfixes the birds so they can easily be killed with a stick or club.

The name mabibi appears to comprise ma-, the relative pronoun (that, which, that which), and bibi, denoting a sucking sound made with the lips (Onvlee 1984), a descriptive label consistent with vocalizations recorded by Coates and Bishop (1997) for the Whitebrowed crake Poliolimnas cinerea and other rails. Informants contrasted mabibi to two larger members of the Rallidae, both frequently found in or near water: kulu kawaki (given by Onvlee as the Red-legged crake Rallina fasciata) and yapi (see Forth 2000). Kambera informants described yäpi, denoting a moorhen Gallinula tenobrosa or G. chloropus, as much larger birds than mabibi and with "dark" or "black" plumage.

Mànja wai, nightjar (Kambera and Lewa; cf. Rindi panyonga makaweda), probably most often referring to the Savannah nightjar Camprimulgus affinis. Responding to my descriptions of this morphologically and behaviorally very distinctive bird, Kambera informants compared the bird's appearance to that of an owl and further described nightjars as birds encountered only at twilight or after dark, when they can be seen either in flight or sitting on the ground (including on asphalt roads). One man related how manja wai will alight on the ground "like a bird dropping dead or injured from the sky" but when one approaches the bird, it will immediately take off, thus making the species extremely difficult to catch. Similar accounts of nightjars quickly taking flight when approached were recorded in Lewa and also in Rindi, where a different name for the bird refers specifically to this behaviour (see below).

All of the foregoing corresponds to the appearance and behaviour of nightjars. Kambera informants further described the bird as typically occurring in "cool or cold places," a description which apparently refers to the fact that Sumbanese encounter nightjars at night and usually in flat, open areas including savannahs and bare ground far from vegetation and exposed to winds. The characterization may also be reflected in the name. Mànja can be interpreted as a contraction of manjaku or mànjalu, both meaning "cool," whereas wai is "water." Although no one I asked knew what manja wai ate or where they go in the daytime, in fact nightjars feed on flying insects, many of why occur over bodies of water. However, the birds are by no means always found near water, and it is possible that, in this context, wai has some other sense or derivation.

Referring to their appearance only at night and lack of evidence regarding their diet or daylight habits, one man described nightjars as strange creatures, even comparing them to spirits and speculating that, at sunrise, the birds might transform into some other creature. Probably adding to their mystery is the local idea that nightjars are legless. Two men spontaneously reported this feature, though immediately afterwards both qualified it by stating that the bird does have legs but that these are extremely small. This representation is of comparative interest as it is also encountered among the Nage people of Flores, the large island located to the north of Sumba, where people similarly alternate between describing nightjars as legless and as birds possessing very small legs (Forth 2004).

The nightjar is also called mànja wai in the district of Lewa, where people claimed that the birds are able to see thieves and that the noctural cry of a nightjar indicates that thieves are abroad. Interestingly, the same symbolic significance was attached to the nightjar's cry by Sumbanese questioned in 1999 in Kupang (Timor) who gave the bird's name as landu witu (Forth 2000). This term, however, was unknown to everyone I questioned in 2015, so its status remains uncertain.

Responding to my descriptions of the bird, people in Rindi identified the nightjar as panyonga makaweda, thus correcting a provisional identification of the name as referring to a kind of bat. Confirming my translation of the name as "fools elderly people" (Forth 2000), Rindi informants explained the name as referring to the characteristic behavior of nightjars encountered in the evening: anyone seeing a specimen resting on the ground might think it is dead or injured, but when a person approaches more closely the bird immediately takes flight, thus "fooling" the observer. Why it should be old people who are specified in the nightjar's name, however, no one could say. Informants confirmed that nightjars are not classified as bats (panii), even though Sumbanese classify both as "birds" (mahawurungu) and recognize both as creatures that are exclusively active at night.

\section{Folk-Intermediates}

Mostly from information recorded in Rindi, I previously identified several folk-intermediate taxa (sensu 
Berlin 1992) each incorporating a number of bird generics (Forth 2000). These can now be reviewed.

Diurnal raptors. Like Rindi people questioned in the 1970s, Kambera informants described ikitu as a general category subsuming the following individually -named diurnal raptors (hawks, eagles, or falcons):

1) Ikitu barangguku ("white-throated ikitu"), the Brahminy kite Haliastur indus (cf. Rindi ikitu marakuku, Forth 2000).

2) Mbaku, identified as ikitu which live near the sea and catch fish. However, one informant distinguished between mbaku tehiku ("sea mbaku") and mbaku, the first term then specifying the Whitebellied sea eagle Haliaetus leucogaster and the Osprey Pandion haliaetus - both identified from photographs. If this distinction is made consistently, mbaku alone should then apply to eagles or other large raptors which occur only inland. The same distinction was recorded in Rindi in the 1970s (Forth 2000:177) although there mbaku tehik $u$ was identified only with $H$. leucogaster.

3) Tariku, identified as a falcon that flies extremely fast and appears as it were out of nowhere to take chickens (unlike larger raptors whose attacks, informants said, can be anticipated). The further specification that tariku will sometimes just 'cut off the head' of domestic fowls recalls the Nage (central Flores) idea that the falcon they name bele teka, "sharp wing," uses its wing like a sickle to decapitate fowls (Forth 2016).

4) Kapăha, a small falcon, described in Parai Liu as hovering, and eating small chickens and grasshoppers, a characterization that would confirm the bird's earlier identification as the Moluccan kestrel Falco moluccensis (Forth 2000:174).

While Onvlee (1984) lists kola as an otherwise unidentified small raptor, Sumbanese questioned in Kupang, in 1999, described the bird as a raptor almost as large as an eagle (Forth 2000:188). All I learnt in Kambera was that kola is not a local bird name but a term employed in the interior district of Mahu for large raptors which Kambera speakers call ikitu. Consistent with this, I have never recorded kola (also glossed by Onvlee as 'speckled, flecked') as a bird name in Rindi. Information recorded in Kambera supports my earlier, provisional interpretation of kun as denoting the Black-winged kite Elanus caeruleus bypolencos (Forth 2000:175) but I am unable to confirm this identification.
Parrots. Kambera informants identified the Psittaciformes labeled kaka (Yellow-crested cockatoo Cacatus sulphurea), kàriku (Eclectus parrot Eclectus roratus), katala (Great-billed parrot Tanygnatltus megalorynchos) and piribu (Rainbow lorikeet Trichoglossus haematodus) as all belonging to a "single group" (satu kelompok, Indonesian). The way in which this was initially revealed is worth elaborating. Translating kariku with Indonesian burung nuri (parrot), one man quickly qualified this by stating that there are two kinds (of kàriku): kariku and piribu, of which kariku was the larger. Later, he described both katàla and kaka as also forming a single group with kàriku and piribu. (No one was familiar with a fifth category, wowangu, denoting the Red-cheeked parrot Geoffroyus geoffroyi; see Forth 2000). As Kambera informants pointed out, all these birds were trapped in former times because all could be trained to talk. A visual expression of the standard pairing of piribu (Rainbow lorikeet), and kaka (Yellowcrested cockatoo) in Sumbanese ritual speech is shown in Figure 1. In my earlier study I stated that the five named parrot categories recorded for eastern Sumbanese (here including wowangu) "do not compose a distinct intermediate grouping-or at least not one that is named" (Forth 2000:173). Information from Kambera mostly qualifies this statement: they do compose a recognized folk-intermediate taxon albeit one which, like many folk-intermediates, is covert.

Larger Columbiformes. In Forth (2000) I described larger Columbiformes as composing a single intermediate taxon named rawa, a term which also polysemously designates a member specified as rawa kamukumu, the Green imperial pigeon Ducula anea. Composing a total of six, all names distinguishing kinds of rawa similarly comprise rawa plus a modifier, but how many taxa these distinguish remains unclear in view of the treatment of some as synonyms of others (Forth 2000:178-79). This may suggest that rawa in the most inclusive sense could alternatively be interpreted as a polytpic folk generic incorporating a number of named folk-specifics. However, in view of the Rindi representation of the imperial pigeon as a bird quite distinct from other rawa, and because this species and other large Columbiformes (e.g. rawa tana, the Emerald ground-dove) possess quite different symbolic and metaphorical profiles, it seems reasonable to treat the several rawa-or some of them at least-as distinct folk-generics (see also Forth 2012 regarding dhéke [rat, mouse] as a named intermediate among the Nage of central Flores). 


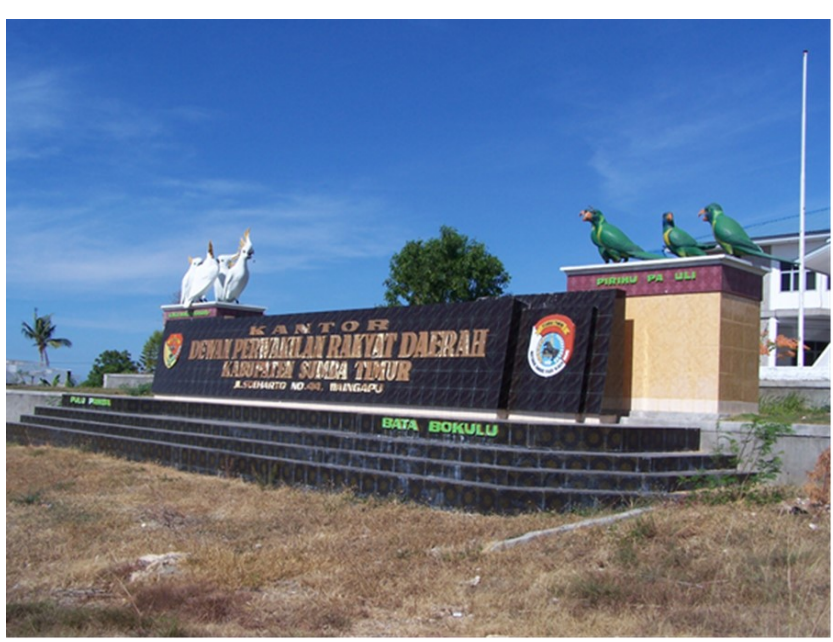

Figure 1 Plaque in front of the offices of the Regency of Sumba Timur (East Sumba) showing cockatoos (kaka) on the left and lorikeets (pirihu) on the right. Beneath the bird figures are written the complementary phrases kaka makanguhuru//pirihu pauli which in formal speech refer to large groups of people gathered together to prosecute an important undertaking (G. Forth).

Information on larger Columbiformes recorded in Kambera in 2015 is comparable to what I recorded in Rindi in 2000, although two Rindi names (rawa ratu and rawa kakoruku) were not recognized by Kambera informants. Binomials of rawa given by Kambera informants included rawa nggawi, an obvious variant of Rindi rawa kawi which previously seemed unique to Rindi (Forth 2000:178) and which may refer to the endemic Sumba green pigeon Treron teysmannii. All this is consistent with the status of Rindi speech as a variant of Kambera, in which regard it is noteworthy that, in both cases, speakers are often aware of differences in regional usage.

While expressing doubt as to its veracity, one man mentioned the indigenous idea that rawa kamuku$m u$, the Green imperial pigeon Ducula aenea, is unable to alight on the ground as it would die it did so. The same idea applies to the imperial pigeon in the Keo region of south-central Flores (where this bird is also named rawa). By contrast, among the Nage, who reside immediately to the north of Keo, inability to alight on the ground is attributed to the Asian paradise-flycatcher Terpsiphone paradisi, specifically in opposition to the Brown quail Coturnix ypsilophora, which is described as unable to perch in trees. Confirming Forth (2000:168), none of the information recorded in Kambera suggested that smaller doves labeled mbara (see below) are included in the grouping labeled rawa. Thus, insofar as rawa denotes a polytypic folk-taxon-either a folk-intermediate or folk-generic - this obviously does not include all Columbiformes known to the eastern Sumbanese, and since all pigeons and doves are, for example, killed and eaten, there appear to be no cultural criteria which, in addition to size, could explain the classificatory separation of larger and smaller kinds (rawa and mbàra).

Bats. Contrary to an earlier suggestion that bats may compose a "possible intermediate" (Forth 2000:171), with panii designating both flying foxes (Pteropus spp.) and a larger class additionally including smaller species, information from Kambera tends to confirm my alternative interpretation of panii as labeling a single folk-generic subsuming all bats. Responding to questions, a Kambera informant described panii ru kaluu (meaning "banana leaf bat") as simply denoting immature specimens of larger bats; the term, however, more likely refers to Microchiropterans that frequent banana trunks, thereby distinguishing a folk-specific subsumed in panii interpreted as a folk-generic (see Onvlee 1984; also the Rindi contrast of panii bokulu and panii kudu, terms which simply mean "large bat" and "small bat," Forth 2000:180). According to the same informant, panii palinju wiki ("bat that fouls itself'), another phrase recorded by Onvlee, refers simply to a general habit of bats, as they normally rest hanging upside down and so regularly urinate (palinju) on themselves. If this is correct, then rather the name of a taxon, the expression is probably a metaphor which refers to certain kinds of human behaviour.

Since the primary referent of pahomba, another term given in Rindi for a kind of small bat (Forth 2000:180), is in fact a kind of spirit, I am now inclined to understand its earlier reported application to bats as a reference to small Chiropterans as animal forms these spirits can assume, rather than as a name for a distinct bat ethnotaxon. As noted above, panyonga makaweda, a term not known in Kambera, actually refers in Rindi not to a bat but to the nightjar. Another correction concerns an earlier suggestion that the name panii (or pani in Onvlee's transcription), also the word for "to speak, talk," designates bats by reference to the chattering vocalization of flying foxes (Forth 2000:180). As a reference to bats, panii reflects PMP *paniki, "flying fox" (Blust 2002:107), and as shown by distinct cognates of panii as the term for "bat" and in the sense of "to speak" in western Sumbanese languages, the two senses evidently reflect 
different protoforms. Furthermore, in the sense of "to speak" eastern Sumbanese panii is apparently constructed of a root (ni) plus the commonly fused prefix pa- (cf. Klamer 2009:254).

\section{Polytypic generics and folk-specifics}

Although the subject of polytypic generics (folkgenerics comprising two or more folk-specifics, sensu Berlin 1992) was not addressed in Forth (2000), the earlier evidence revealed three instances: mbàra, 'small dove', comprising two named specifics (mbàra manu and mbàra nggela), mbaku, "eagle, large hawk," insofar as the category admits a distinction of mbaku tehiku and at least one other kind of mbaku, and rendi ('duck'), comprising at least two specifics. As discussed above, rawa (pigeon, larger dove) can now be understood as another instance of a polytypic generic, as can panii (bat). As mentioned in Forth (2000:174), people in Rindi stated there were two unnamed kinds of terns (Sterninae), karata, while a Sumbanese informant interviewed in 1999 in Kupang similarly described a "pure white" kind of tern, which is found near inland waters, and a cream-colored kind "with dark marks on the back of the head" which occurs in coastal regions. How exactly these may align with the several species of terns occurring on Sumba I am unable to determinate. Nevertheless, karata, can be provisionally interpreted as another polytypic generic, albeit one comprising two covert (unnamed) folkspecifics.

Information recorded in Kambera in 2015 revealed five additional polytypic folk-generics. These include:

1) Kabiku (kingfisher), subsuming two kinds: kabiku luku, "river kahiku," typically found near rivers or other bodies of water, and other kingfishers, simply called kabiku. Here, then, we have another instance of the common polysemy whereby a single term labels both a more inclusive generic and a folk-specific. As kabiku luku was described as having a red bill, the name may specifically refer to the Stork-billed kingfisher Halcyon capensis, whereas the usual referent of kabiku (without qualification) is most likely the Collared kingfisher Halcyon chloris, whose bill is mostly dark-gray. The nominal distinction is comparable to the Nage (central Flores) contrast of fega ae ("water, river kingfisher," H. capensis) and fega wolo ("hill, dry land kingfisher"), the second term usually denoting the White-rumped kingfisher Caridonax fulgidus, another species with a red bill (Forth 2004).

2) Powa (quail). Kambera informants mentioned two kinds of powa, a larger sort named powa manu and a smaller called powa ndau. Here, we find another use of manu, "chicken, domestic fowl" Gallus gallus, to distinguish the larger or largest of two or more kinds. Examples recorded in Forth (2000) include rawa manu, mbàra manu, and rendi manu, labeling respectively larger kinds of pigeons, doves, and ducks. I was unable to establish a relevant sense for the contrasting modifier ndau, in powa ndau. Onvlee's gloss "(covered in) mould, fungus" (1984) suggests it could refer to plumage, but then the term would have to be construed, according to Onvlee's transcription, not as ndau but $n d a^{\prime} u$.

3) Wàngi (owl). In Forth (2000) wàngi is identified, following Onvlee, as specifically denoting the Barn owl Tyto alba. According to Kambera informants, however, it applies to two distinct kinds of owls, including one with striped or mottled plumage, but neither sort is distinguished by name. Here, then, we apparently encounter another instance of covert folk-specifics, and since Coates and Bishop (1997) list only three confirmed species of owls for Sumba-two belonging to the Tytonidae (Barn owls) and one to the Strigidae (the Sumba boobook Ninox rudolfi, an island endemic) - the two covert taxa very likely correspond respectively to members of these two owl families.

4) Kaka (Yellow-crested cockatoo Cacatua sulphurea citrinocristata; the endemic Sumbanese subspecies is also known as the Citron-crested cockatoo). Kambera people speak of two sorts of cockatoos: kaka and kaka ratu (ratu denotes an indigenous religious or ritual leader). Kaka ratu was described as a cockatoo which a long crest which can be either orange or pink. On the other hand, Onvlee (1984), says the binomial refers to a cockatoo with red eyes. Either way, as there is only one species of cockatoo on Sumba, and moreover just one subspecies (Coates and Bishop 1997), kaka and kaka ratu cannot distinguish different ornithological taxa, and since red eyes are specific to females (at least in some subspecies of Cacatua sulphurea; www.parrots.org/encyclopedia/yellow-crestedcocackatoo, site accessed 16 December 2015), the partly distinct names may, as Onvlee's description would suggest, instead reflect sexual differences, 
thereby constituting an instance of "overdifferentiation" in folk biological taxonomy.

5) Kàriku (Eclectus parrot Eclectus roratus cornelia). Forth (2000) describes Rindi people as recognizing kàriku muru and kàriku rara ('green' and 'red' kàriku) as respectively males and females of a single species. While Eclectus males and females are indeed respectively green and red, Kambera informants interpreted the terms as labeling two distinct taxa, each including both males and females, and thus confirming Dammerman's report (1926a:213-14) on Sumbanese bird classification. In that case, the categories reveal another instance of over-differentiation, comparable to that suggested by the contrast of kaka and kaka ratu.

\section{Miscellaneous addenda}

Manginu labels a folk-intermediate comprising a large number of small passerine birds, some further distinguished by name (Forth 2000). At present, the most common kind found in the Kambera region, including the town of Waingapu, is apparently the tree sparrow (Passer montanus). These ubiquitous birds, which throughout Indonesia occupy the same ecological niche as do house sparrows (Passer domesticus) in Europe and North America, arrived on Sumba in 1949 (Coates and Bishop 1987:494). I do not recall seeing any during my two-year sojourn in 1975-76 (hence they are not mentioned in Forth 2000) nor is their presence reflected in Onvlee's or Kapita's dictionaries. During my recent stay in Parai Liu (Kambera) I often observed specimens of the great tit (Parus major), a bird not mentioned in Forth (2000). The birds are noticeably smaller and less colorful than European or Japanese conspecifics. While tree sparrows can be distinguished as manginu kani (Forth 2000:177), so far as I could discover great tits are known only as manginu.

The name toturu laka, given by Onvlee (following Dammerman 1926) for the lesser coucal (Centropus bengalensis), was not recognized in Kambera. Curiously, the only name I recorded for the coucal in 2015, offered by just one informant, was kutuku, which by all other accounts denotes another large dark cuckoo, the Australian koel Eudynamis everetti. As another name listed for the coucal in Forth (2000) is the nearly identical tutuku, 'kutuku' in this context is probably a simple error. The informant, however, remarked how certain of the bird's vocalizations were produced with the anus, an idea previously recorded for the coucal on Sumba (Forth 2000) as well as among the Nage of Flores (Forth 2004), thus indicating that the reference was this bird rather than the koel.

As indicated above, karata, terns (Sterninae), occur not only in coastal areas of Sumba but also near inland bodies of water. The settlement which now forms the administrative centre of the modern regency (kabupaten) of Lewa-a region of lakes, ponds, and paddy fields located in Sumba's interior plateau-is called Pameti Karata, "Death of the Terns," taking its name from a reputedly historical incident in which a flock of terns, flying overhead, suddenly died and fell to the earth. The well-known tale relates no more than this, and I heard no reason-mystical or otherwise-for the birds' sudden demise. This is one of the few instances in which birds lend their names to places in eastern Sumba; other examples, both designating uninhabited locations, include Hibu Kaka ("Cockatoo's Nest[s]") and Hibu Mbaku ("Eagle's Nest"). Among the numerous named patrilineal clans that populate the region, I have only ever come across one which takes its name from a bird. This is Wàngi Rara ("Red Owl"), a binomial which, it should be noted, does not definitely designate either of the covert owl folkspecifics mentioned above.

\section{Summary and Conclusions}

Additional data recorded in 2015 do not significantly affect the outline of eastern Sumbanese folk taxonomy published in Forth (2000). Recent field information affirms ikitu (diurnal raptors), manginu (small passerines), and rawa (larger Columbiformes) as named intermediates while revealing an additional, unnamed (covert) intermediate: "parrots." Including panii (bat, now interpreted as a generic rather than an intermediate taxon) as well as three recently identified instances (kahiku, kingfisher; powa, quail; and wàngi, owl), polytypic folk-generics now number ten. Of these, kaka and kàriku (each comprising two folkspecifics, kaka and kaka ratu and kàriku rara and kariku muru) are further included in the unnamed 'parrot' intermediate. Consistent with this taxonomic elaboration is the prominent occurrence of various parrot generics in eastern Sumbanese symbolic genres, more particularly in myth and parallelistic ritual language (Forth 2000:181-84; see also Figure 1 above) - a point lending support to a view of folkintermediates as often reflecting 'cultural' associations (e.g. Atran 1983). 
A review of 56 eastern Sumbanese bird names recorded in Forth (2000) suggests that 50 denote folkgenerics. To these may now be added the two new generics (denoting egrets and nightjars) recorded in 2015, as well as the single bat generic, panii, thus bringing the total to 53 . Of these, ten, or $18.87 \%$, are interpretable as polytypic folk-generics. The figure for the Nage of central Flores is nine out of 68 bird generics, or $13 \%$. New data brings the number of Sumbanese bird folk-intermediates to four, of which three are named. The comparable Nage figure is six, which includes three named and three unnamed intermediates (Forth 2016:167). In both respects, therefore, eastern Sumbanese bird taxonomy is quite comparable to what is found among the more thoroughly researched Nage.

\section{Acknowledgements}

I am grateful for the assistance of numerous people during my 2015 visit to Sumba, but especially to Domu Hunggurama (aka Boku Lewa), Umbu Angga, and Umbu Mana, his wife Sarah Hobgen, and their extended family, who provided accommodation and hospitality in Parai Liu. Special thanks are also owed to Drs. Bernardus Retang Wohangara, a native of the village of Lambanapu, who supported my visa application and put me in touch with several prospective informants.

\section{Declarations}

Permissions: None declared.

Sources of Funding: Social Sciences and Humanities

Research Council Insight Grant (2013-2017).

Conflicts of Interest: None declared.

\section{References Cited}

Atran, S. 1983. Covert Fragmenta and the Origin of the Biological Family. Man 18:51-71.
Berlin, B. 1992 Ethnobiological Classification: Principles of Categorization of Plants and Animals in Traditional Societies. Princeton University Press, Princeton, NJ.

Blust, R. 2002. The History of Faunal Terms in Austronesian Languages. Oceanic Linguistics 41:89_ 139.

Coates, B. J., and K. D. Bishop. 1997. A Guide to the Birds of W allacea: Sulawesi, the Moluccas and Lesser Sunda Islands. Dove Publications, Alderley, Australia.

Dammerman, K. W. 1926. Soembaneesche DierenEn Plantennamen. Tijdschrift voor Indische Taal-, Landen Volkenkunde 66:205-239.

Forth, G. 2000. Eastern Sumbanese Bird Classification. Journal of Ethnobiology 20:161-192.

Forth, G. 2004. Nage Birds: Classification and Symbolism among an Eastern Indonesian People. Routledge, New York, NY.

Forth, G. 2016. Why the Porcupine is not a Bird: Explorations in the Folk. Zoology of an Eastern Indonesian People. University of Toronto Press, Toronto, Canada.

Kapita, O. H. 1982. Kamus Sumba/Kambera-Indonesia. Percetakan Arnoldus, Ende, Indonesia.

Klamer, M. 2009. The Use of Language Data in Comparative Research: A note on Blust (2008) and Onvlee (1984). Oceanic Linguistics 48:250-263.

Olivier, J. 1931. Inheemsche Taxonomie. De Tropische Natuur 20:1-4.

Onvlee, L. 1984. Kamberaas (Oost-Soembaas)-Nederlands Woordenboek. Foris Publications, Dordrecht, Holland. 